\section{Armenia: Higher Education Problems and Perspectives}

\section{Lovisa A. Antonian}

Louisa A. Antonian works in the International Journalism and International Relations Department, Yerevan H. Acharian University, P.Sevak Street 7, Yerevan 375014, Armenia. Tel: (3742) 64-22-96. E-mail: <lantonian@hotmail.com>.

$\mathrm{D}$ uring the Soviet period the higher education system in Armenia was quite well supported and funded. Unfortunately, in the transition to a market economy the universities are now struggling to survive in the free market. The social, economic, and political changes in the country have had an impact on the entire system of higher education. Some of these changes were initiated by government, others arose in response to market forces now that institutions have become more autonomous and competitive. Meanwhile, declining government support and new funding arrangements and methods have created uncertainty and volatility. Universities can no longer rely on government financing and are turning to other sources of revenue-including student tuition, management of university properties, local businesses, donors, and foreign aid organizations. Despite these challenges and many unforeseeable factors concerning national development, great efforts are being made to update the country's higher education system.

\section{Governance and Funding}

A major aspect of the change process is the self-governance of institutions. There are no laws guaranteeing the autonomy and freedom of institutions of higher education, but the institutions themselves are highly centralized with significant power concentrated in the office of the rector. Faculty have only a slight involvement in governance. As a result, in many cases change has been a lower priority than simple institutional survival.

Currently, universities receive 80 percent of their revenue from tuition fees (which range from U.S.\$300 to $\$ 1,500$ per student), 45 percent of which are returned to the state budget. Only a small amount of the state's receipts are reinvested in higher education. Thus, as the government provides less money for the management of universities, the primary concern of rectors and administrators is funding. Universities have started to charge fees for the use of university properties and for various services to generate income for staff salaries.

As a result of various factors-including high unemployment rates, new career aspirations, and significant deepening of inequality in access to education-the number of young people seeking to continue their studies after high school has risen sharply. Some 80 percent of high school students planning to go on to higher education enroll in private classes to prepare for admissions exams, at an average cost of $\$ 588$ per subject. In addition to the 15 previously operating state institutions of higher education, there are now 87 private universities and institutes. As of January 1,1998 , state institutions of higher education had enrollments of 35,900 students-19,100 state funded (i.e., tuition-free), while the rest were charged tuition. In addition, private institutions enrolled 20,000 students. The state budget for state-funded students is very low and has been declining year by year: for instance, during the 1996-1997 academic year the expenditure was just \$261 per student.

However, the absence of a clear concept of the structure of state-funded education remains a serious issue. After more than a decade of reform, the National Assembly of Armenia only recently ratified the law on education. The delay can be explained by the frequent changes within the Ministry of Education and Science as well as by the difficulties in defining the extent of state-funded education.

One of the changes involves accreditation. Graduates from private universities did not have the same standing as those from state universities. However, some of them have gained equal standing due to recent standardized accreditation procedures. This is especially true of those institutions that ensure quality and possess modern facilities and revised and up-to-date courses in such areas as business management and international law, among others.

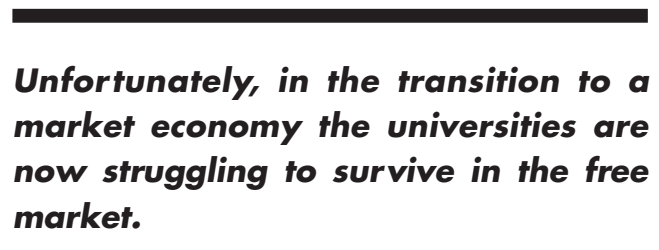

Curricular Change

The demands of new social and economic development require reshaping of the curriculum. A key effort has been the increase in both the quality and number of course offerings. Since the 1980s, attempts have been made at universities to achieve a balance between economics-oriented and social science programs. These progressive developments have involved existing departments, as well as newly created ones-such as departments of political science and public affairs. In addition, universities have enrolled experts to design a curriculum that addresses the social and economic needs of today. For instance, they have introduced social science approaches in business and economics courses. In most cases, these improvements-based on Western models- have succeeded. However, some cases require more detailed research and a deeper understand- 
ing of the specific context of the region. It is not enough just to transplant Western curricula, they should be transformed to work in a specific setting.

\section{Faculty Updating and Training}

The decline in funding for higher education has also affected the economic position of the faculty. University professors who have spent their careers transmitting what is already known, are not equipped to create new, advancedlevel knowledge. For instance, those who formerly taught "scientific communism" may now be teaching "political science." However, they retain traditional methods and programs. It is mostly the senior academic staff (doctoral candidates or degree holders) who are in need of an updating of their disciplinary knowledge and expertise.

However, today a reevaluation of these disciplines is under way. Universities are attempting to reorganize academic faculties by recruiting experts whose ideas are consistent with the reforms (i.e., persons with advanced training in Western universities) or by recruiting staff (from lab assistants to the highest rank of professors) on a competitive basis. The Ministry of Education and Science has also recently developed a distance-learning program to fill the gaps in expert training. Language training, especially in English, is required to enable faculty to communicate with colleagues in their field outside Armenia.

Many universities and institutes now realize that training new and old academic staff for the new curriculum will require a long-term commitment. Still, the existing environment complicates the task of faculty training. Some pro- fessors feel on the defensive and unsure about the validity of the changes. Others, especially senior faculty, are still opposed to change. Moreover, the fact that the faculty are often forced to find outside work to supplement their salaries decreases the amount of time they can spend on teaching and research. Besides, only teaching has been broadly funded, while research funding is in very short supply. Even when a proposal is approved, after peer review, by the $\mathrm{Na}$ tional Academy of Sciences of Armenia and the Ministry of Education and Science, it often dies for lack of funding. This situation has resulted in a brain drain problem for the country's education system.

\section{An Action Plan}

Finally, to bring the universities and their faculties into line with higher education in the West, an 8-to-10-year action plan is being developed, based on the achievements and lessons of the transition period. The plan includes the following goals: 1) improve communications among universities in order to provide better coordination; 2) stimulate the formation of a dynamic system of higher education to encourage improvement of quality and expanding the range of programs offered; 3 ) raise the profile and value of accreditation of programs and institutions of higher education; and 4) foster and introduce innovative institutional structures and make the most effective use of new technology.

Author's note: This article was supported in part by the Bureau of Educational and Cultural Affairs of the U.S. State Department. The opinions expressed here are the author's own.

\section{Bridging the Gap between Higher and Secondary Education in Russia}

\section{Anna Smolentseva}

Anna Smolentseva is on the staff of the Center for Sociological Studies, Moscow State Lomonosov University. Address: 11 Mokhovaya Ul., Moscow, Russia 103009. Tel.: (095) 203-60-74; Fax: (095) 203-6334; E-mail: <anna@opinio.msu.ru>.

$\mathrm{T}$ he successful functioning of the educational system as a social institution requires maintaining continuity and consistency between different levels, especially secondary and higher education. This poses a challenge for educators and policymakers seeking to ensure sustainable development of a national system of education. In Russia, the interaction between secondary and higher education has become a serious problem that must be resolved in the near future.

\section{Rising Demand}

Traditionally, Russian higher education was designed to prepare highly qualified professionals or specialists. Admission to public universities, which comprise about two-thirds of all Russian universities, is based on applicants' perfor- mance on entrance examinations. In the last five years, the demand for higher education has grown to historic levels: in 1999, there were 246 students per 10,000 population. Nevertheless, the proportion of the population in Russia that participates in higher education (2.4 percent) is much smaller than that in most developed countries. University entrance examinations have become much more competitive. In 1999, there were more than 200 applicants for every 100 places in public universities. In the most prestigious universities, the number of applicants can amount to as many as 12 to 14 for each place.

\section{Admissions Requirements}

A major problem is the significant gap between highly demanding university entrance examinations and the insufficient levels of knowledge that school graduates possess. This gap means that secondary school graduates need additional preparation to gain admission to higher educational institutions. According to some estimates, no more than onethird of students enter university while relying solely on 